\title{
HUBUNGAN ASUPAN DAN KADAR OMEGA-3 PLASMA DENGAN KEJADIAN HIPERTENSI PADA ETNIK MINANGKABAU DI KOTA PADANG
}

\author{
Delmi Sulastri \\ Bagian Ilmu Gizi Fakultas Kedokteran Universitas Andalas \\ E-mail : delmisulastri@yahoo.com
}

Abstrak

Hipertensi merupakan masalah kesehatan utama di Indonesia maupun di dunia Hampir 95\% kasus hipertensi tidak diketahui penyebabnya atau disebut hipertensi esensial (HET). Pola konsumsi yang baik dan seimbang merupakan salah satu upaya pengendalikan tekanan darah. Omega-3 adalah salah satu zat gizi yang dapat menurunkan tekanan darah. Omega-3, terbukti berperan dalam mencegah beberapa penyakit kronis termasuk hipertensi.

Telah dilakukan penelitian dengan desain cross sectional study untuk melihat hubungan omega-3 plasma dengan kejadian hipertensi. Penelitian dilakukan pada 130 orang yang terdiridari subjek hipertensi dan normotensi. Pengambilan sampel dengan cara sistematik random sampling dengan memperhatikan kriteria inklusi dan ekslusi. Asupan omega-3 dihitung menggunakan FFQ dan kadar omega-3 plasma diukur dengan teknik methylasi.

Hasil penelitian ini adalah asupan omega-3 adalah 0,66 $\pm 0,61$ gram/hari, EPA 0,29 \pm 0,23 gram/hari, DHA (22:6) 0,85 0,65 gram/hari dan kelompok normotensi ALA 0,64 \pm 0,55 gram/hari, EPA 0,27 $\pm 0,15$ gram/hari, DHA 21,34 $\pm 174,14$ gram/hari. Tidak terdapat perbedaan bermakna asupan omega-3 dengan kadar omega-3 plasma antara kelompok hipertensi dengan kelompok normotensi dan tidak terdapat hubungan yang bermakna antara asupan omega-3 dan kadar omega3 plasma dengan kejadian hipertensi.

Hasil penelitian ini tidak mendukung hubungan antara omega-3 dengan kejadian hipertensi

Kata kunci : hipertensi, omega-3, EPA, ALA, DHA

\section{Abstract}

Hypertension is the leading health problem in the community in Indonesia and even in certain countries all over the world. Almost $95 \%$ of hypertension cases are from unknown cause which is also known as essential hypertension (HET). Planned and balanced consumption pole is one of the efforts to control blood pressure. Omega-3 is one of the nutrients that reduce blood pressure. Omega-3 is proven to involve in preventing certain chronic disease including hypertension.

A cross-sectional study carried out to identify the correlation between Omega-3 plasma and the hypertension incidence. 130 subjects were selected and divided 
into groups of hypertension and normotension. The subjects were chosen using randomized systemic sampling method inconsideration of inclusive and exclusive criteria. Omega-3 consumption measured by FFQ and Omega-3 plasma measured using methylasi technique

The study's result shows The hypertensive's consumption of omega-3 was

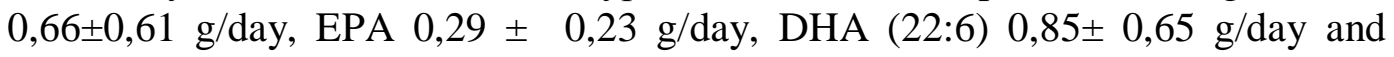
normotension was ALA 0,64 \pm 0,55 g/day, EPA 0,27 $\pm 0,15 \mathrm{~g} /$ day, DHA 21,34 \pm $174,14 \mathrm{~g} /$ day. no significant differences was found in either omega-3 consumption and Omega-3 plasma level between the hypertension and normotension groups and no significant correlation between the intake and omega-3 plasma level with the incidence of hypertension.

This result didn't support that omega-3 can influenced hypertension in subject Key word : hypertension, omega-3, EPA, ALA, DHA 


\section{Pendahuluan}

Hipertensi merupakan suatu penyakit yang ditandai dengan peningkatan tekanan darah di atas nilai normal, dengan nilai sistolik $\geq 140$ $\mathrm{mmHg}$ dan diastolik $\geq 90 \mathrm{mmHg}$ (Kriteria Join National Commitee / JNC VII, 2003). Saat ini hipertensi sudah menjadi masalah utama kesehatan masyarakat di Indonesia maupun di beberapa negara di dunia. ${ }^{(1)}$ Data dari The National Health and Nutrition Examination Survey (NHNES) menunjukkan dari tahun 1999 - 2000 insiden hipertensi pada orang dewasa adalah $29 \%-32 \%$, ini berarti bahwa terdapat $58-65$ juta orang menderita hipertensi di Amerika dan terjadi peningkatan 15 juta dari data tahun $1988-1991^{(2)}$

Prevalensi hipertensi di seluruh dunia sekitar $15-20 \%$ sedangkan di Asia sudah mencapai $8-18 \%$. Pada tahun 2025 diperkirakan terjadi kenaikan kasus hipertensi sekitar $80 \%$, yaitu dari 639 juta kasus di tahun 2000, menjadi 1,15 milyar kasus pada tahun 2025. ${ }^{(2,3)}$

Prevalensi hipertensi di Indonesia berkisar antara $17 \%$ sampai $21 \%$, sedangkan menurut laporan Depkes RI pada tahun 2007, prevalensi hipertensi di Indonesia sudah mencapai

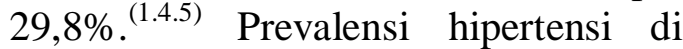
Sumatera Barat cenderung meningkat. Pada tahun 1977 prevalensi hipertensi hanya $7,3 \%,{ }^{(5)}$ kemudian pada tahun 2005 Decroli dkk melaporkan bahwa prevalensi hipertensi di Sumatera Barat telah mencapai $27,3 \%$ dan pada tahun yang sama, Azmi melaporkan 25,39\% dan data terakhir dari hasil riset kesehatan dasar yang dilakukan departemen kesehatan RI tahun 2007, prevalensi hipertensi di Sumatera Barat sudah mencapai 31,2\%. ${ }^{(6-8)}$ Sekitar 95\% penderita hipertensi tidak diketahui penyebabnya dan dikenal sebagai hipertensi primer atau esensial. Faktor utama yang berperan dalam patofisiologi hipertensi adalah interaksi faktor genetik dengan faktor lingkungan. ${ }^{(8)}$ Hipertensi primer tidak disebabkan oleh faktor tunggal dan khusus. Hipertensi ini disebabkan berbagai faktor yang saling berkaitan. Risiko relatif hipertensi tergantung pada jumlah dan keparahan dari faktor risiko yang dapat dimodifikasi dan yang tidak dapat dimodifikasi. ${ }^{(9)}$

Upaya pencegahan hipertensi dapat dilakukan dengan menerapkan gaya hidup sehat. Pola konsumsi yang baik dan seimbang merupakan salah satu upaya pengendalikan tekanan darah. Omega 3 adalah salah satu zat gizi yang dapat menurunkan tekanan darah. Senyawa ini banyak ditemukan pada ikan. ${ }^{(10.11)}$ Omega 3 merupakan asam lemak tak jenuh yaitu eikosapentaenoat (EPA) dan dokosaheksaenoat (DHA) dan banyak ditemukan pada berbagai jenis ikan seperti sardin, tuna, cakalang, kembung, tenggiri atau mackarel, salmon, trakulu, kakap dan sebagainya. Beberapa jenis ikan laut Indonesia seperti bawal, tuna, tenggiri, sidat, dan ikan layang memiliki kandungan asam lemak Omega 3 sangat tinggi yaitu 10.9 gram/100 gram. $^{(12)}$

Peran Omega-3 mulai dianggap penting berdasarkan penelitian pada tahun 1970-an terhadap orang-orang Eskimo yang banyak makan ikan. Saat ini omega-3, terbukti berperan dalam mencegah beberapa penyakit kronis seperti hipertensi. Peran omega-3 terhadap hipertensi adalah dengan cara mencegah agregasi platelet dan mengefektifkan respon vasomotor, mempengaruhi respon pembuluh darah, keseimbangan sodium, perubahan pelepasan renin dan secara langsung mengefektifkan kerja jantung. ${ }^{(13)}$

Negara Indonesia memiliki perairan yang tergolong sangat luas, 
bahkan tiga kali lipat lebih luas dari pada daratannya, tetapi konsumsi ikan rakyat Indonesia baru $26 \mathrm{~kg}$ per kapita per tahun (berdasarkan data Ditjen Pengawasan dan Pengendalian Kelautan dan Perikanan tahun 2007). Data ini sangat rendah jika dibandingkan dengan keadaan penduduk Malaysia, Thailand, dan Singapura yang mengkonsumsi ikan melebihi $40 \mathrm{~kg}$ per kapita per tahun, atau Amerika Serikat yang mengkonsumsi ikan sekitar $80 \mathrm{~kg}$. Bahkan penduduk Jepang dan Korea Selatan mengkonsumsi ikan mencapai $140 \mathrm{~kg}$ per kapita per tahun. Konsumsi ikan untuk masyarakat Sumatera Barat adalah 58,4 gram perhari (lebih kurang $21 \mathrm{~kg}$ pertahun). ${ }^{(14)}$

Berdasarkan data-data yang telah dipresentasikan di atas, maka peneliti tertarik melihat hubungan antara konsumsi dan kadar omega-3 plasma dengan kejadian hipertensi pada penerita hipertensi etnik Minangkabau.

\section{Metoda Penelitian}

Desain Penelitian : Penelitian ini adalah studi komperatif dengan desain penelitian cross sectional study.

Lokasi dan waktu penelitian

Penelitian dilakukan di 4 kecamatan di kota Padang provinsi Sumatera Barat, dimulai dari bulan Juli 2009 s/d Desember 2009.

Populasi dan sampel

Populasi adalah semua penderita hipertensi dan normotensi yang berusia antara 30 - 65 tahun, etnik Minangkabau (berdomisili di Sumatera Barat, kedua orang tua dan kakek nenek berasal dari Sumatera Barat) dan diperoleh melalui penjaringan terhadap 800 orang sampel yang tersebar di 4 kecamatan di Kota Padang Prov. Sumatera Barat. Sampel diambil dengan menggunakan rumus untuk $n 1=n 2=\left(z \dot{\alpha} \sqrt{ } 2 P Q+z \beta \sqrt{ } P_{1} Q 1+P 2 Q_{2}\right)^{2}$ $/(P 1-P 2)$, didapatkan jumlah $\mathrm{n} 1=\mathrm{n} 2=$ 62 orang, dengan pertimbangan DO $10 \%$ maka total sampel untuk $\mathrm{n} 1$ dan $\mathrm{n} 2$ adalah 130 orang.

Sampel diambil dengan cara porposif untuk menentukan kecamatan yang mewakili dengan 2 daerah berlokasi di sepanjang pantai dan 2 daerah lainnya berada jauh dari pantai. Hal ini dilakukan atas pertimbangan perbedaan pola makan di antara kedua lokasi tersebut. Dari ke 4 kecamatan dilakukan pemilihan daerah tempat pengambilan sampel dengan cara multi stage random sampling sedangkan sampel diperoleh dengan memperhatikan kriteria eksklusi (Hipertensi sekunder, perokok berat, menjalani diet, post operasi saluran pencernaan) pada tiap - tiap lokasi yang sudah ditentukan dilakukan dengan metoda sistematik random sampling.

Pengumpulan data

Data karakteristik diperoleh melalui wawancara menggunakan kuesioner serta asupan makanan khususnya omeg-3 dinilai dengan menggunakan formulir semiquantitatif Food Frequency Questioner (FFQ) dan diolah menggunakan program nutrisurvey. Data kadar omega-3 plasma diperoleh dari hasil pemeriksaan $3 \mathrm{cc}$ serum sampel penelitian di laboratorium LIPI Jakarta.

Analisis data

Analisis univariat, untuk melihat distribusi data masing - masing variabel dan kemudian disajikan dalam bentuk tabel atau diagram. Data terdiri dari karakteristik, asupan dan kadar omega-3 (EPA, ALA'dan DHA) plasma.

Analisis bivariat, untuk melihat hubungan antara variabel dependen dengan variabel independen dengan 
menggunakan t-test dan chi-square Subjek penelitian adalah masyarakat dengan derajat kepercayaan $95 \%$. asli Minangkabau yang berusia antara 30 - 65 tahun dan bertempat tinggal di

Hasil Penelitian lokasi terpilih. Pada tabel 1 dapat dilihat

Karakteristik Subjek, Demografi dan karakteristik dari subjek penelitian.

Status Sosial.

Tabel 1. Karakteristik Subjek Penelitian

\begin{tabular}{lccccc}
\hline $\begin{array}{l}\text { Karakteristik Subjek } \\
\text { Penelitian }\end{array}$ & \multicolumn{2}{c}{ Kasus } & \multicolumn{2}{c}{ Kontrol } & p \\
\cline { 2 - 4 } & $\mathbf{f}$ & $\mathbf{\%}$ & $\mathbf{f}$ & $\mathbf{\%}$ & value \\
\hline Jenis Kelamin & & & & & \\
$\quad$ Pria & 14 & 21.5 & 14 & 21.5 & 1.00 \\
$\quad$ Wanita & 51 & 78.5 & 51 & 78.5 & \\
Umur & & & & & \\
$\quad$ < 40 tahun & 3 & 4.6 & 8 & 12.3 & 0.11 \\
$\quad$ 40 tahun & 62 & 95.4 & 57 & 87.7 & \\
Tingkat pendidikan & & & & & \\
$\quad$ Rendah & 42 & 64.6 & 37 & 56.9 & 0.06 \\
$\quad$ Tinggi & 23 & 35.4 & 28 & 43.1 & \\
$\quad$ Status Pekerjaan & & & & & \\
$\quad$ Tidak Bekerja & 36 & 55.4 & 34 & 52.3 & 1.00 \\
$\quad$ Swasta & 20 & 30.8 & 24 & 36.9 & \\
$\quad$ PNS/ABRI & 9 & 13.8 & 7 & 10.8 & \\
\hline
\end{tabular}

Pada tabel 1 dapat dilihat bahwa baik kelompok hipertensi maupun normotensi, subjek penelitian dengan jenis kelamin wanita lebih banyak dibandingkan laki-laki yaitu 51 orang $(78.5 \%)$ dan sebagian besar sampel berusia $\geq 40$ tahun yaitu 62 org (95.4\%) pada kelompok hipertensi dan 57 orang $(87.7 \%)$ kelompok normotensi. Subjek dengan tingkat pendidikan rendah lebih banyak pada kedua kelompok masing-masing $64,6 \%$ pada kelompok hipertensi dan 56,9\% pada kelompok normotensi.

\section{Gambaran Asupan Asam Lemak} Omega-3 Subjek Penelitian

Pada masing-masing kelompok hipertensi dan normotensi didapatkan rata-rata konsumsi asam lemak omega-3 adalah sebagai berikut untuk

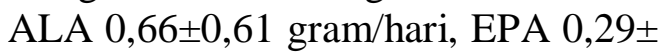
0,23 gram/hari, DHA $0,85 \pm 0,65$ gram/hari dan kelompok normotensi ALA 0,64 \pm 0,55 gram/hari, EPA 0,27 $\pm 0,15 \mathrm{gram} / \mathrm{hari}$, DHA $21,34 \pm$ 174,14 gram/hari. Total asupan asam lemak omega-3 pada populasi hipertensi adalah 1,79 \pm 1.23 gram/hari, 
dan pada populasi normotensi $2,28 \pm 1.64$ gram/hari. Untuk lebih jelasnya terlihat pada tabel di bawah ini :

Tabel 2. Rerata Asupan Omega-3 Subjek Penelitian

\begin{tabular}{lccc}
\hline & Hipertensi & Normotensi & $\begin{array}{c}\mathbf{P} \\
\text { value }\end{array}$ \\
\cline { 2 - 4 } Variabel & $\begin{array}{c}\text { Mean } \pm \text { SD } \\
\text { gram/hari }\end{array}$ & $\begin{array}{c}\text { Mean } \pm \text { SD } \\
\text { gram/hari }\end{array}$ & $\begin{array}{c}\text { Median } \\
\text { gram/hari }\end{array}$ \\
\cline { 2 - 4 } Omega- & $1,79 \pm 1.64$ & $2,28 \pm 1.23$ & 0.69 \\
3 & & & \\
ALA & $0,66 \pm 0,60$ & $0,64 \pm 0,55$ & 0,82 \\
EPA & $0,29 \pm 0,23$ & $0,27 \pm 0,15$ & 1,00 \\
DHA & $0,84 \pm 0,65$ & $1,37 \pm 4,697$ & 0,62 \\
\hline
\end{tabular}

Tidak terdapat perbedaan yang signifikan asupan asam lemak omega-3 antara kelompok hipertensi dengan kelompok normotensi $(p>0,05)$.

\section{Rerata Kadar Omega-3 (Plasma} ALA, EPA dan DHA)

Dari hasil penelitian ini didapatkan rerata hasil pemeriksaan asam lemak Omega-3 pada kelompok hipertensi adalah $14.45 \pm 0.10 \mathrm{ug} / \mathrm{dl}$ dengan uraian sebagai berikut untuk ALA 3,22 $\pm 0,21 \mathrm{ug} / \mathrm{dl}$, EPA 3,96 $\pm 0,42$ ug/dl, DHA 7.27 $\pm 0,78$ ug/dl dan kelompok normotensi rerata kadar omega-3 plasma ádalah $14.49 \pm 1.0$ ug/dl dengan kadar ALA 3,26 $\pm 0,20$ ug/dl, EPA 3,89 $\pm 0,41 \mathrm{ug} / \mathrm{dl}$ dan DHA $7,31 \pm 0,808 \mathrm{ug} / \mathrm{dl}$. Tidak terdapat perbedaan bermakna kadar omega baik EPA, ALA maupun DHA plasma antara kedua kelompok.

\section{Tabel 3. Rerata Kadar Omega-3} Plasma Subjek Penelitian

\begin{tabular}{lccc}
\hline \multirow{2}{*}{ Variabel } & Hipertensi & Normotensi & \\
\cline { 2 - 3 } & Mean \pm SD & Mean \pm SD & \\
\hline Omega 3 & $14.45 \pm 0.10$ & $14.49 \pm 1.0$ & 0.86 \\
ALA & $3,256 \pm 0,235$ & $3,29 \pm 0,210$ & 0,143 \\
EPA & $3,93 \pm 0,392$ & $3,91 \pm 0,408$ & 0,871 \\
DHA & $7,27 \pm 0,377$ & $7,31 \pm 0,808$ & 0,745 \\
\hline
\end{tabular}

Hubungan kadar ALA, EPA, DHA plasma dengan kejadian hipertensi dapat dilihat pada tabel berikut :

Tabel 4. Hubungan Kadar Omega-3 Plasma dengan Kejadian Hipertensi

\begin{tabular}{clccccc}
\hline \multirow{2}{*}{ Zat Gizi } & \multirow{2}{*}{ Kategori } & \multicolumn{4}{c}{ Kelompok } & P \\
\cline { 3 - 5 } & & \multicolumn{2}{c}{ Hipertensi } & \multicolumn{2}{c}{ Normotensi } & value \\
\cline { 3 - 5 } Omega-3 & Kurang & 42 & 51.9 & 39 & 48.1 & 0.72 \\
& Cukup & 23 & 35.4 & 26 & 53.1 & \\
\cline { 3 - 5 } & Kurang & 45 & 55,6 & 36 & 44.4 & 0.14 \\
ALA & Cukup & 30 & 42,9 & 40 & 57,1 & \\
& Kurang & 37 & 48,7 & 39 & 51,3 & 0.87 \\
EPA & Cukup & 38 & 50,7 & 37 & 49,3 & \\
& Kurang & 41 & 51,3 & 39 & 48,8 & 0.75 \\
DHA & Cukup & 34 & 47,9 & 37 & 52,1 & \\
\hline
\end{tabular}


Dari tabel di atas dapat dilihat bahwa kadar omega-3, ALA dan DHA yang kurang lebih banyak ditemukan pada kelompok hipertensi $(55.6 \%$ dan $51.3 \%$ ), sedangkan kadar EPA yang kurang lebih banyak pada penderita normotensi (51.3\%). Hasil uji statistik tidak ada didapatkan hubungan yang bermakna antara kadar omega-3 plasma dengan kejadian hipertensi $(p>0,05)$.

\section{PEMBAHASAN}

Subjek pada penelitian ini merupakan keterwakilan masyarakat pantai dan jauh dari pantai dengan proporsi yang hampir sama untuk kedua daerah. Dari seluruh subjek penelitian sekitar $47 \%$ adalah masyarakat pantai dan sisanya sekitar 53\% adalah masyarakat yang jauh dari pantai. Secara geografis kecamatan yang terpilih mudah dicapai dari pusat kota sekitar $20 \mathrm{~km}$ untuk kecamatan yang terjauh yaitu Kecamatan Lubuk Kilangan dan jarak terdekat sekitar 2 km untuk Kecamatan Kampung Jao. Letak yang potensial tersebut menyebabkan keterjangkauan masyarakat untuk mendapatkan bahan sumber makanan khususnya ikan sebagai sumber omega-3 dengan mudah diperoleh untuk keempat lokasi kecamatan ini.

\section{Konsumsi Asam Lemak Omega-3 (ALA, EPA, DHA) Subjek Penelitian}

Rerata konsumsi omega-3 ALA pada subyek hipertensi adalah $0,66 \pm 0,61$ gram/hari dan pada kelompok kontrol 0,64 $\pm 0,55$ gram/hari. Hasil penelitian ini tidak jauh berbeda dengan penelitian yang dilakukan oleh Hulshof KF et al pada tahun 1999; yang mendapatkan konsumsi ALA di Negara Perancis adalah 0,6 gram/hari. Dari hasil penelitian tidak terdapat perbedaan bermakna konsumsi ALA antara kelompok hipertensi dengan normotensi. ${ }^{(15)}$

Rerata konsumsi EPA pada populasi hipertensi $0,29 \pm 0,23$ gram/hari, dan pada populasi normotensi $0,27 \pm 0,15$ gram/hari dan rerata konsumsi DHA didapatkan pada kelompok hipertensi sebesar 0,85 \pm 65 gram/hari dan pada kelompok normotensi 1,37 \pm 4,69 gram/hari. Asupan EPA lebih rendah dan DHA lebih tinggi dari yang telah di rekomendasi The International Society for the Study of Fatty Acids yaitu konsumsi EPA dan DHA masingmasing adalah 0.5 gr/hari. ${ }^{(15)}$ Sedangkan hasil penelitian yang dilakukan oleh William Harris, et al merekomendasikan konsumsi EPA dan DHA antara $0.25-0.5$ gr/hari. ${ }^{(16)}$ American Heart Association merekomendasikan konsumsi EPA dan DHA 1 gram/hari untuk pasien yang telah diketahui mempunyai penyakit kardiovaskuler dan $0.40-0.50 \mathrm{gr} /$ hari untuk yang tanpa penyakit kardiovaskuler. ${ }^{(17)}$ Hasil penelitian berbeda yang dilakukan oleh Barbara JM et al (2003) mendapatkan rerata konsumsi EPA pada 10.851 orang dewasa di Australia adalah 0,06 gram/hari dan rata-rata konsumsi DHA adalah 0,11 gram/hari. Perbedaan hasil ini kemungkinan disebabkan oleh perbedaan karakteristik dan pola konsumsi masyarakat dan jumlah responden yang diambil. ${ }^{(16)}$

Hasil uji statistik penelitian ini tidak terdapat perbedaan yang bermakna konsumsi EPA dan DHA pada populasi hipertensi dan normotensi. Hasil ini berbeda penelitian yang dilakukan oleh Hannah ET (2007) pada subjek yang diberi konsumsi 0,7 gr/hari DHA dibandingkan dengan subjek yang diberi plasebo untuk melihat efek DHA terhadap fungsi vaskuler pada 38 
orang laki-laki dan perempuan yang berumur antara 40-65 tahun selama 3 bulan dengan hasil terjadi penurunan tekanan darah diastolik sebesar 3,3 mmHg. Penelitian ini menunjukan bahwa konsumsi DHA sebanyak 0,7 gr/hari dapat menurunkan tekanan darah diastolik tetapi belum tampak perannya dalam fungsi endotelial dalam jangka pendek. ${ }^{(18)}$

Penelitian lain pada tikus percobaan dilakukan untuk melihat efek omega-3 yaitu DHA dan EPA terhadap tekanan darah pada hewan coba hipertensi yang diberikan makanan DHA atau EPA selama 2 bulan sebanyak $240 \mathrm{mg} / \mathrm{hari}$, didapatkan bahwa konsumsi DHA menginduksi penurunan tekanan darah, tidak demikian konsumsi EPA. ${ }^{(19)}$

Pada penelitian ini didapatkan rerata konsumsi omega-3 pada populasi hipertensi adalah 1,79 gr/hari dan pada populasi normotensi 2,28 gr/hari. Hasil ini telah melebihi rekomendasi yang dikeluarkan oleh American Heart Association (AHA) 400 - $500 \mathrm{mg} / \mathrm{hari}$. Sedangkan Australia National Health and Medical Research Concil merekomendasikan konsumsi omega-3 pada wanita $410 \mathrm{mg} /$ hari dan pada laki-laki $630 \mathrm{mg} / \mathrm{hari}$. Pada penelitian yang dilakukan oleh Karen JM, et al mendapatkan bahwa pada subjek hipertensi yang diberikan konsumsi omega-3 sebanyak 3 - 5,6 gr/hari selama 3-24 minggu efektif menurunkan tekanan darah sistolik sebanyak 3-4 mmHg dan menurunkan tekanan darah diastolik sebanyak 5,5 mmHg. ${ }^{(15)}$

Penelitian yang dilakukan oleh Luc Djousse, et al mendapatkan bahwa konsumsi omega-3 sebanyak 3 gr/hari selama 6 minggu dapat menurunkan tekanan darah pada subjek dengan hipertensi sebanyak 5 mmHg. ${ }^{(20)}$ Hasil penelitian lain yang dilakukan oleh Hirotsugu Ueshima et al mendapatkan bahwa terdapat hubungan yang signifikan antara konsumsi total omega-3 dengan hipertensi. ${ }^{(21)}$ Sedangkan hasil penelitian Trevor A. Mori dkk mendapatkan bahwa efek anti hipertensi omega-3 dengan konsumsi 3,65 gram/hari. ${ }^{(22)}$ Omega-3 telah digunakan sebagai terapi tambahan seperti penelitian yang dilakukan di Rusia terhadap 22 pasien dengan hipertensi dan sindroma metabolik yang diberikan 1,5 gram omega 3 selama 1 bulan dapat menurunkan tekanan darah pasien hipertensi. ${ }^{(23)}$

Mori TA menyatakan bahwa efek kardio protektif omega-3 berhubungan dengan perbaikan tekanan darah, fungsi jantung, tahanan arteri dan fungsi vaskuler. Mori TA menyatakan bahwa EPA dan DHA mempunyai peranan yang berbeda. DHA kemungkinan lebih berperan dalam penurunan tekanan darah dan denyut jantung dengan mekanisme memperbaiki fungsi vaskuler, meskipun penelitian ini juga mendapatkan bahwa efek EPA dan DHA berbeda bergantung kepada target populasi. ${ }^{(24)}$ Berdasarkan penelitian yang dilakukan oleh Luc Djouse (2005) mendapatkan bahwa omega-3 yang terdapat pada ikan dapat menurunkan tekanan darah pada pasien yang mengkonsumsi omega-3 sebanyak > 3 gram/hari. ${ }^{(20)}$

Penelitian yang dilakukan oleh Hirotsugu Ueshima dkk (2007) pada The International Study of Macro and Micro-nutrients and Blood Pressure (INTERMAP) yang merupakan studi epidemiologi internasional cross sectional terhadap 4680 subjek penelitian laki-laki dan perempuan yang berada di negara Cina, Jepang, Inggris dan Amerika Serikat menda-patkan hasil bahwa terdapat hubungan antara konsumsi omega-3 subjek penelitian 
dengan tekanan darah yang diukur sebanyak 8 kali pada 4 kali kunjungan. ${ }^{(21)}$

\section{Hubungan Kadar Plasma Asam} Lemak Omega-3 dengan Hipertensi

Hasil penelitian ini didapatkan kadar plasma asam lemak omega-3 pada populasi hipertensi adalah 14,3 ug/dl; sedangkan pada populasi normotensi 14,4 ug/dl. Hasil penelitian ini berbeda dengan penelitian yang dilakukan oleh Lipoeto (2002) yang mendapatkan kadar omega-3 plasma pada etnis Minangkabau yang tidak mengkonsumsi kelapa adalah 6,2 ug/dl dan kadar asam lemak omega-3 plasma pada kelompok yang mengkonsumsi kelapa adalah $8,3 \mathrm{ug} / \mathrm{dl} .^{(14)}$ Beydoun MA dkk melakukan kohor studi pada subjek penelitian yang berumur antara 50-65 tahun $(n=7814)$ pada tahun 1987 (kunjungan pertama) sampai tahun 1998 (kunjungan ke empat) dengan menganalisis konsumsi makanan menggunakan food frequency questionnare dan pemeriksaan plasma asam lemak di Minnesota mendapatkan bahwa peningkatan konsumsi omega-3 dapat menurunkan resiko hipertensi. ${ }^{(24)}$

Pada penelitian ini tidak terdapat hubungan yang signifikan antara kadar omega-3 plasma (ALA, EPA dan DHA) dengan kejadian hipertensi dengan $\mathrm{p}$ value $>0,05$. Hasil penelitian ini tidak sesuai dengan hasil penelitian yang dilakukan Cicero dkk (2009) yang menyatakan bahwa omega-3 secara signifikan dapat menurunkan tekanan darah dengan mekanisme menurunkan produksi vasokonstriktor dan menurunkan aktifitas enzim renin-angiotensin. ${ }^{(25)}$

Penelitian lain yang dilakukan oleh Simon GA, et al (2009) yang melibatkan 174 subjek berusia antara 45 - 74 tahun. Pemeriksaan yang dilakukan meliputi pengukuran kecepatan gelombang tekanan aorta, tekanan darah dan komposisi asam lemak plasma. Analisa hubungan semua pemeriksaan tersebut adalah bahwa proporsi kadar DHA dan EPA lebih tinggi dalam plasma dan secara siknifikan menurunkan resiko peninggian tekanan darah. ${ }^{(26)}$

\section{KESIMPULAN}

1. Asupan omega 3 pada kelompok hipertensi dan normotensi sudah sesuai dengan angka kecukupan gizi dan tidak terdapat perbedaan bermakna asupan omega 3 antara kelompok hipetensi dengan normotensi.

2. Tidak terdapat hubungan kadar asam lemak omega 3 (ALA, EPA dan DHA) dengan kejadian hipertensi.

\section{KEPUSTAKAAN}

1. Armilawaty, Amalia $\mathrm{H}$ dan Amiruddin. Hipertensi dan faktor risikonya dalam Kajian epidemiologi. Bagian Epidemiologi. FKM UNHAS. 2007.

2. Woodwell DA. Advance data from vital and health statistics, in National ambulatory Medical Survey. National Center for Health Statistics Hypertension 44: 419.

3. Hadi H, 2005. Beban Ganda Masalah Gizi dan Implikasinya Terhadap Kebijakan Pembangunan Kesehatan Nasional. Pidato Pengukuhan Jabatan Guru Besar pada Fakultas Kedokteran UGM Yogyakarta. 2000. 
4. Dinas Kesehatan Provinsi Sumatera Barat. Profil Kesehatan Provinsi Sumatera Barat. 2007.

5. Darmojo Perjalanan B. Mengamati Hipertensi Medika: 2001; 1: 442-448.

6. Kumala M. Penatalaksanaan nutrisi pada hipertensi. Dalam Pegangan Penatalaksanaan Nutrisi Pasien, Jakarta. 2000 : $92-6$.

7. Azmi S. Peran angiotensin II reseptor antagonis dalam pengobatan hipertensi, dalam Naskah Lengkap Pertemuan Ilmiah Berkala VI Ilmu Penyakit Dalam. September. 2005. Padang, FK-Unand. $\mathrm{p}$ 16-25.

8. Decroli E., Manaf A., Syahbuddin S.Hypertension inimpaired glucose tolerance in West Sumatera, ADES. Congress, Manila. 2005

9. Yogiantoro M. Hipertensi Essensial, dalam buku Ajar Ilmu Penyakit Dalam.Pusat Penerbitan Departemen Ilmu Penyakit Dalam FKUI. Jakarta; 2007 : hal 599-603.

10. Neil JS. Fish Consumtion, Fish Oil, Lipid, and Coronary Heart Deseases. American Heart Association, Inc. 1996.

11. Peter K. Penyakit Jantung Koroner. Gramedia Pustaka Utama, Jakarta. 2009: hal 2143.
12. Direktorat Jendral Pengawasan dan Pengendalian Kelautan dan Perikanan. Konsumsi Ikan Masyarakat Indonesia. Diunduh dari www.goegle .co.id. 2007.

13. Peter M. Biosintesis Asam Lemak. Dalam Biokimia Harper. 2003. EGC. Jakarta.

14. Lipoeto, NI. Kadar Asam Lemak Omega Tiga dan Konsumsi Produk Kelapa pada Etnik Minangkabau di Sumatera Barat, Proceeding Kongres Nasional PDGMI, Bandung. 2006.

15. Karen JM., Barbara JM. Impact of Food Enriched With Omega-3 Long Chain Polyunsaturated Fatty Acid on Erythrocyte Omega-3 Level and Cardiovasculer Risk Factors. Division of Health Sciences and Nutrition, Adelaide, Australia. 2006.

16. William H., Dariush M. Towards Establishing Dietary Reference Intakes for Eicosapentaenoic and Docosahexaenoic Acid. The Journal of Nutrition. 2009.

17. Richard J., Deckelbaun., Sharon RA. n-Fatty Acid and Cardiovascular Desease : Navigatting to Ward Recommendations. American Journal of Clinical Nutrition. 2006.

18. Hannah ET., Alison H., Goodall. Low Dose DHA Lowers Diastolic Blood Pressure in Middle Aged Men 
and Women. The Journal of Nutrition.

19. Ross R.The Pathogenesis of Atherosclerosis an Update. New England Journal of Medicine. 1986. 499-501.

20. Luc Djousse., Domma K., Arnet. Relation Between Diet Alpha Linolenic Acid with Lowering Prevalence Hypertension to NHLBI Family Heart Study. American Heart Association. 2005.

21. Hirotsugu U., Jeremiah S. Food Omega-3 Fatty Acid Intake of Individual (Total Linolenic Acid Long Chain) and Their Blood Pressure. American Heart Association, Inc. 2007.

22. Trevor AM., Danny QB., Valerie B., Lan BP., Lawrence JB.Docosahexaenoic Acid but Not Eicosapentaenoic Acid Lowers Ambulatory Blood Pressure and Hearth in Human. American Association Heart, Inc. http//www.nlm.nih.gov/entrez/ query d.fegi.

24. Beydoun MA., Kaufman JS., Sloane PD. n-3 Fatty Acid, Hypertension and Risk of Cognitive Decline Among Older Adults in The Atherosclerosis Risk in Communities (ARIC) Study. Centre of Human Nutrition, Departemen of International Health, Baltimore. USA. 2008.

25. Cicero AF., Ertek S., Borghi C. Omega-3 Polyunsaturated Fatty Acid : Their Potensial Role in Blood Pressure Prevention and Managemet Hipertension. Research Unit, Internal Medicine, Aging and Kidney Diseases, Bologna Italy. 2000.

26. Simon G Anderson et al, 2009. Plasma Fatty Acid Consumtion as a Predictor of Arterial Stiffnes and Mortality Hypertension. American Heart Association.
23. Vasil ev., Streltsova NN, Sekisova MA.Effect of Omega-3 on The Serum Lipid Profile and Microcirculation in Patiens with Metabolic Syndrome and Hypertensive Diseases. 